\title{
Creative Commons Licenses for Transmedia Storytelling Content
}

\author{
By Marco Aurélio Rodrigues da Cunha e Cruz* \\ Andrea Cristina Versuti
}

It is undeniable that witnesses a sharp increase in the flow of information that influence the construction of the society in different ways. For constructive and inventive making this society, communication and information technologies subsidise new ways of recording, storage and distribution of text, sound and images. This offer features enables access of more people to innovative modes of production, creation and registration of cultural goods, knowledge and information. Here lies the indispensability of rereading what shall be to the copyright, the subject of this writing. During the past few decades, the legal protection of authorship of cultural property were based on a control system of space and movement, however nowadays the content is mediated by different platforms (websites, social networks, radio, movies) in order to meet a greater number of viewers / consumers. The content is diluted within a new architecture of actors. One of the greatest examples of this dialogic form of production of cultural goods is a communication strategy that organises content and platforms to tell a story: transmedia storytelling. Indeed, the reflection of the legal protection of authorship of cultural property in the XXI Century leads to the proposal of Creative Commons, which focus is to create a cultural property of the universe that can be accessed or processed in accordance with the voluntary consent of the author. The aim of this paper is to examine if the author of transmedia storytelling to protect his content can use a legal adaptation of the Copyright Act (LDA - Law 9.610 /98) proposed by Creative Commons in Brazil. The deductive method, with allowance in literature and the succession of the following steps are used: performs a brief analysis of the history of copyright, we study the doctrine concerning the concepts developed in the text, the procedure is the interpretation of how the transmedia storytelling and Creative Commons can relate.

Keywords: Cultural Property, Legal Protection of authorship, Creative Commons, Transmedia Storytelling.

\section{Introduction}

If before the legal protection of authorship of cultural property were based on a control system of space and movement, today content is mediated by

\footnotetext{
* Pofessor, Faculdades Alves Faria/Alfa, Goiânia, Brazil.

* Professor, Universidade Federal de Goiás/Regional Jataí, Jataí, Brazil.
} 
different platforms (websites, social networks, radio, movies) in order to meet a greater number of viewers / consumers. The content is diluted within a new architecture of actors, given today by the directivity function of search tools or own social networks. Its functionality is far from exhausted by the reception of content and enables properly his amendment and further dissemination. All content is the basis for new content. Every receiver is a link in passing. One of the greatest examples of this dialogic form of production of cultural goods is a communication strategy that organises content and platforms to tell a story: the transmedia storytelling, the epicentre of this work.

Indeed, for the reflection of the legal protection of authorship of cultural property in the XXI Century won capillarity the proposal of Creative Commons (CC), which focuses, as the responsible for the project in Brazil, is "to create a cultural property of the universe that can be accessed or processed in accordance with the voluntary consent of the author" ${ }^{1}$. The aim of this paper is to examine whether to protect the authorship of transmedia storytelling can use a legal adaptation of the Copyright Act (Law 9.610 / 98) proposed by Creative Commons. The deductive method, with allowance in literature and the succession of the following steps are used: performs a brief analysis of the history of copyright, we study the doctrine concerning the concepts developed in the text, the procedure is the interpretation of how the transmedia storytelling and Creative.

\section{Brief History of Copyright}

Not objective of this topic exhaust the historical of the copyright. However, for the argumentative text line, it is necessary to make a few comments on some background.

Nonetheless, the Brazilian Copyright act (9.610/98) was made for a society in which the media not transcended the current interactive social practices that lead to an "electronic knowledge-based economy, information and intangibles (such as image and connections)". ${ }^{2}$ For Castells ${ }^{3}$ innovation in this model of society that we are living, is the primary function. Innovation depends on knowledge generation facilitated by free access to information, and this information is online, networked.

The consequences of this form of sociability, based on the freedom of access and production of cultural goods, is enhanced by the interaction done in real time. The effects of the network that lead to Castells (2003) proposes an "Internet culture", which is based on (1) flexibility; in (2) the absence of a command centre and (3) maximum autonomy of each node. It is a culture that presupposes a technocratic belief in the progress of humans mediated by technology, which thrives by free and open technological creativity, based on

\footnotetext{
${ }^{1}$ Lemos (2005a) 184.

${ }^{2}$ Castells (2003) 85.

${ }^{3}$ Ibid.
} 
virtual networks that aim to reinvent the society, and materialised by entrepreneurs' powered money in the gears of the new economy.

It is true that the availability of reproduction, recreation and dissemination of intangible property, a participatory and collaborative dimension never before achieved, raises questions about the notion of the individual-author (actor) and their socio-cultural, philosophical and legal grounds ${ }^{1}$. New concepts to interpret the new reality complain changes in conceptions of space, writing, time and relationship. The way of thinking of the actors absorbs new network logic, "excesses, agility, integration, relativism and young expertise" ${ }^{2}$. And this social logic of innovation, productivity and economic growth has not been achieved by "legislative time" law governing relations of copyright. In this respect, on the legal adaptation of copyright to the current media is that deal with the following topics.

\section{Collaborative Immaterial Labour and Transmedia Storytelling}

In the transition between post-industrial capitalism and a society grown by information and collaborative work, products that previously would have its value based on regulatory principles are capitalists of goods controlled by copyright laws as possible and preferably open content. It is unmistakable that the advent of new technologies of communication and information deploys a support creative new means of communication / language, and the work in an electronic medium, experiments with new collaborative forms of production, circulation and reception.

Clovis Montenegro Lima and Lima Rose Marie Santini ${ }^{3}$ observed that the source of productivity in the information society emerges from technologies that enable the creation of knowledge, information processing and communication of symbols. Are tools that allow the actors to develop their ideas, possible software that will process information (formerly ideas) and that the information generated intensely affect the social context, thus showing the intrinsic connection between the productive forces, communication and culture. Networks leverage this type of society because, as Castells ${ }^{4}$, have extraordinary organizational advantages, because of its flexibility and adaptability, essential characteristics to survive and thrive in the rapidly changing environment, as is the case in contemporary societies.

The economy in this context, therefore, walks to the growing appreciation of intangible property, the dispute by technical knowledge, and information processing by computer code to your gateway ${ }^{5}$. Is not immune also the classic category of immaterial labour (mainly individual), therefore this work mode tends to be enhanced by collaborative immaterial labour. When the immaterial

\footnotetext{
${ }^{1}$ Magalhães (2008).

${ }^{2}$ Pimentel \& Fuks (2012) 26.

${ }^{3}$ Lima \& Santini (2008a).

${ }^{4}$ Castells (2007).

${ }^{5}$ Magalhães (2008).
} 
labour is recognised as a fundamental basis of production, this process does not direct its attention exclusively to production, but for the "reproductionconsumption" cycle. The immaterial labour, in fact, not flying in the exclusive form of "exploitation", but it can be the construction of subjectivities ${ }^{1}$.

These forms of immaterial labour nourish a dependency of communicative and collaborative network shares, of which result new networks of interpersonal relations (intellectual, emotional and social). Emerge as new behaviours, psychological traits, different cycles of knowledge, rationality, reserve, isolation, mobility, punctuality that integrate a new subjective organization $^{2}$. These working models provide other possibilities to run with the logic of the cooperative and collaborative body necessary for the production, groupware - Trudy Johnson-Lenz - or Computer Supported Cooperative Work (CSCW) - Irene Greif and Paul Cashman - who in Brazil have been translated into "collaborative systems"3. These systems are envisioned in order to collaborate, interact and share, without a rigid hierarchy, which encourages the creation and informality. There are those who think that this potential can be also conjectured in political and social self-organization ${ }^{4}$.

Changes in communication and information technology therefore become the immaterial work processes so that they give feedback to the model of ICTs. The use of computers, tablets and all the machinery that enables the connection is indispensable in the production of the current immaterial work and enables a vast room for creating and collaboration among users across the world. It is through them that the development of information, a story, a text, a movie - in short, of all the possible "products" of the network - it is not an individual process and becomes a collaborative production.

The collaborative productions therefore mark a phenomenon resulting from the great development of the communities in networks, the result of the information age that is characterised by its source of productivity and seems to find in digital technologies to generate knowledge, information processing and communication symbols ${ }^{5}$. Clovis Montenegro Lima and Lima Rose Marie Santini ${ }^{6}$ suggest that this collaborative informational mode of development is through an "abstract cooperation", which gives a more central place to information and communication skills. However, those who do not cooperate need to be present in the same place and may be unknown to each other, or known only in sharing information. There must be, for this ontology of collaboration: (1) motivation of a group to achieve a common goal, (2) communication between the participants, (3) coordination and organization efforts, work plan and (4) cooperation or production results in a shared space ${ }^{7}$.

In this tone, once opened, the information is taken by a community or a network that implements and develops synergy and in the end, the whole is

\footnotetext{
${ }^{1}$ Lima \& Santini (2008a).

${ }^{2}$ Pimentel \& Fuks (2012).

${ }^{3}$ Pimentel \& Fuks (2012).

${ }^{4}$ Lima, Santini \& Lisboa (2007).

${ }^{5}$ Castells (2007).

${ }^{6}$ Lima \& Santini (2008a).

${ }^{7}$ Pimentel \& Fuks (2012).
} 
worth more than the sum of the parts ${ }^{1}$. In the context of collaborative production, the private ownership of any products / artefacts "intermediaries" can prevent the continuity of the creative process, not just its universal ownership by actors.

It is within the collaborative creation universe are the various platforms such as blogs, forums and specific sites that are directed to the development of new ideas, software, knowledge and cultural goods in general. The technologies that converge gradually, creating an environment where information can be accessed by various means and in different ways, seem to enhance the new social relations of creative and collaborative work and create a favourable environment for the spread of imagination and new work.

The development of ICTs, the demands for greater interaction and better communication have resulted in a media convergence through which the content is transmitted by different platforms (websites, social networks, radio and movies) in order to meet a greater number of actors. Currently, it is common to find stories that expand, going beyond its original media and bypassing other. The contents are adapted to the type of media that are, thus generating new experience for the actors.

To Henry Jenkins ${ }^{2}$, this convergence is characterised by three key technologies: phone, TV and computer. It is undeniable synergy between these three platforms. On the web there are specific sites to watch videos, and playing the role of television (as Vimeo or YouTube), and we also television on mobile phones and smartphones - phones that function as small computers. All characterised by its portability, going against what the actors want: connection and mobility.

According to the author, convergence is not only a technological process that combines multiple functions within the same apparatus, but it is also a process of cultural transformation in which it is possible to identify new levels of participation of fans, new ties with the content new guidelines for contemporary marketing, new copyright laws, new ways to measure audience. That is, given the multiplicity of platforms, subjects are encouraged to seek information, make connections among the dispersed media content. In short, it is not the platform that converges, but the user.

This range of different platforms set up an increasingly multimedia society, where different media can be used separately or jointly to build communication processes. In this scenario, there stage for that meditate on the concept of collective intelligence ${ }^{3}$ in which knowledge of a particular subject is is built from the involvement of many parties in the communication process. It is this interaction that ensures broader understanding of a particular cultural product offered.

Within this new culture of convergence is born transmedia narrative, transmedia storytelling or, as designated by theorists like Henry Jenkins ${ }^{4}$ and

\footnotetext{
${ }^{1}$ Pimentel \& Fuks (2012).

2 Jenkins (2009).

${ }^{3}$ Levy (1993).

${ }^{4}$ Jenkins (2009).
} 
Carlos Scolari ${ }^{1}$, adopting the term often for entertainment products, but also to different fields such as education and information, with the main foundation cognitive reconstruction from multiple platforms.

A transmedia story develops through multiple media supports, with each new text contributing distinct and valuable way to the whole. In the ideal form of transmedia narrative, each medium does what it does best - so that a story can be introduced into a movie, be expanded to television, novels and comic; your universe can be explored in video games experienced the attraction in an amusement park $^{2}$.

In transmedia storytelling, the history of the universe is fragmented across multiple platforms and expands with each new medium in which is told, thus enriching the narrative experience whether for education, information, trade etc. Basically, transmedia narrative is a communication strategy that organises content and platforms to tell a story ${ }^{3}$. One way to motivate the public to intensely experience the narrative is to enable participation that can be over the internet, with the creation of blogs related to the plot, participating in forum discussions or virtual communities, sharing, thus, opinions and new forms of creation that serve in the development of the narrative ${ }^{4}$.

However, it is certain that the classical copyright model, in more restrictive and patrimonial feature, can be a form of attachment to these collaborative and creative productions, as in the case of transmedia storytelling. This is because the society of XXI Century, the intellectual property of intangible assets is opposed to exclusively privatísticos interests. The production of artificial scarcity conflicts with the collaborative production and sharing. The copyright system is to be reread and reinterpreted, otherwise no longer serve $e^{5}$. The protection of copyright (not by chance is now called intellectual "property"), as news Lawrence Lessig ${ }^{6}$ requires control not only the the creativity of commercial breeders, but to all people. In collaborative and shared context, the "intellectual property" of "intermediate" prevents not only universal access to cultural heritage but also the fluidity of the creative process. More flexible license usage, copying and dissemination invite therefore the participation in this process, and not succumb to the mere choice between products in the "market" of information and cultural goods ${ }^{7}$. However, a biased biased interpretation of copyright model does not allow this flexibility, and not be restricted to just a regular "copy", but its control tends to be too expansive.

It is in this sense update the copyright regime that was created by Lawrence Lessig Creative Commons project (CC), whose goal is to expand the amount of creative works available, allowing the creation of other works on them, and facilitating the sharing. This procedure is developed and provided by

\footnotetext{
${ }^{1}$ Scolari (2008).

2 Jenkins (2009).

${ }^{3}$ Gosciola (2012).

${ }^{4}$ Reno, Versuti \& Reno (2012).

${ }^{5}$ Lima \& Santini (2008b).

${ }^{6}$ Lessig (2005).

${ }^{7}$ Lima, Santini \& Lisboa (2007).
} 
legal licenses that allow access to works under flexible terms ${ }^{1}$. What about the relationship between transmedia storytelling and Creative Commons licenses is going to be described in the next section.

\section{Transmedia Storytelling and Creative Commons}

The main message of this topic is that there are legal alternatives that provide better interaction between the disclosure and the author's rights. The impasse that exists between the classical model of copyright and new alternatives emerge when it protects only to that which produced the knowledge and have the immediate right of the work. A careful reading of the law protects the author and limits the dissemination of works and knowledge, mitigating the primary function of knowledge: to reach the largest possible number of people.

In fact, the classic copyright protection contrasts with the new models of distribution of information. Facilitated communication "unprotects" the author and reaches therefore the information cycle (author, channel and receiver). Reality shows us that every day millions of people hurt the copyright on the Internet, which, even today, was not enough to be a change in national legislation $^{2}$.

The actuality requires the author's rights are not inflexible as to favour only the interests of the authors, not as open in order to think only in the interests of society. This questioning therefore gravitates on the balance between the protection of copyright holders and access to knowledge and freedom of expression by society ${ }^{3}$. In this sense, the alternatives have emerged that seek to protect the author and facilitate the dissemination of information listed below.

The fair use doctrine originated in the United States and tries to be a balance between the proprietary model information and the interest of the community. She shares the use of fair, legitimate or appropriate, unfair and inappropriate, that configure violation of copyright. Patricia Peck Pinheiro ${ }^{4}$ explains that the fair use allows access to works available without the need to acquire them. It is a concept that limits the copyright under some circumstances, such as use in education.

This doctrine can be used to treat the use of works on the Internet, serving to fill a legal gap that is not enough to regulate copyright in the digital age for two reasons: it facilitates access to protected information and makes it difficult to obtain the permission of the author. According to this model, the person concerned may use a work protected by copyright to study, copy, and comment on, among others, without the express permission of the author or the copyright holder.

\footnotetext{
${ }^{1}$ Lemos \& Branco (2006).

${ }^{2}$ Paranaguá \& Branco (2009).

${ }^{3}$ Fundação Getútlio Vargas (2011).

${ }^{4}$ Pinheiro (2013).
} 
Manuella Silva dos Santos $^{1}$ argues that, with the fair use doctrine of the US law equalise to copyright protection and access to intellectual creation. It is therefore "an important tool in the preservation of access to information that companies and balances the individual interests of the author and the community." Despite the positive aspect of the doctrine of "fair use" in literal translation, would not have it effect in Brazil, where the prevailing civil law system or preview system, which system greatly limits the work of authors. ${ }^{2}$

In turn, copyleft is a job that was started from the thought of free software $^{3}$, this brainchild of Richard Stallman, founder of the Free Software Foundation (FSF). It was therefore a legal innovation with an emphasis on constructive force of immaterial labour ${ }^{4}$, based on so-called four fundamental freedoms: a) freedom to run the program for any purpose; b) freedom to study how the program works, and adapt it to your needs; c) the freedom to redistribute copies with attention to otherness; d) freedom to improve the program and make its flow improvements, so that all may benefit ${ }^{5}$. This license uses the copyright system to allow all people have access to freely information: the information should be passed on.

Copyleft not give up the copyright, but uses its own law to give rise to the use of the product by others. License, so the rights of the copyright, but require all licensees to make reference to the author of the work and to use the same licensing model in redistributions of the same original, copy or derived versions. The copyleft license, because it prevents the author of the licensed work, and that future authors of works derived from it may exercise restrictions on access to work under conditions of direct equity compensation ${ }^{6}$.

It aims copyleft licenses: a) protect the copyright, but spread their work; b) mitigate the restriction of access to work, against the volition of the author and beyond what considers necessary as a reward; c) ensure the work is not vulnerable to ruinous lawsuits; d) create free culture environments, with movement and construction of immaterial work openly ${ }^{7}$. The licensees with copyleft licenses can avail himself of others works under the granted license. This type of license can be internalised in Brazil because copyleft aims, among other objectives, to preserve the authorship of the work ${ }^{8}$. The parallel can be made with public license agreements, and not all that unique feature of equity rights to exploit the work, according to the private autonomy of the author established. This license must grant the licensee the "four freedoms related to implementation, study, withdrawal and distribution of copies, as well as the modification of the original work and creation of derivative works." 9

\footnotetext{
${ }^{1}$ Santos (2008) 152.

${ }^{2}$ Paranaguá \& Branco (2009).

${ }^{3}$ Lemos (2005b).

${ }^{4}$ Fonseca (2006),

${ }^{5}$ Paranaguá \& Branco (2009) 111.

${ }^{6}$ Tavares \& Angels (2010).

${ }^{7}$ Lima \& Santini (2008) 124.

${ }^{8}$ Santos (2008) 156.

${ }^{9}$ Tavares \& Angels (2010) 204.
} 
In turn, the essence of the Creative Commons (CC) comes from the word commons, which in English means common or popular, being related to common places to everyone as squares, parks, roads, beaches and even in the works public domain, i.e. commons is what everyone can use without having to ask anyone's permission ${ }^{1}$. It is what might be called the right to collective goods or public goods.

The CC is used as a system in which they operate several licenses arranged so as to provide greater freedom of movement with more protection to the author according to your interest. He is the author who chooses as the license will be regulated. From the DC use, the author of any intellectual work such as text, photos, music, movies, database, software or any other work protectable by copyright, can license their works through public license it believes appropriate authorizing thus the collective use their works within the license chosen by the author limits. So the CC is called collaborative project and admits permit for any creative work. The CC licenses covering possibilities between total prohibition of the uses of a work (all rights reserved) and the public domain (no copyright). It is, therefore, a medium term (some rights reserved). Thus the author to opt for one CC license retains the copyright while allowing certain uses of his work.

In this context, the potential of transmedia narrative can be, in this sense, better suited for $\mathrm{CC}$ licenses according to the possibilities offered or restriction of movement consented by the author of immaterial work. This is because with the CC also seeks the spread of immaterial work. And the essence of transmedia storytelling takes place, as said, with the contents disseminated dialogue on the platforms. Authors can choose to specific licenses, which best suit their interests, within existing options. CC licenses can be managed for "any works such as music, film, text, photo, blog, database, compilation, software or liable work of copyright protection"2.

These public license (listed on http://creativecommons.org/), can be classified as atypical contracts, and unilateral are governed by the principles of contracts. It is certain, therefore, that through its flexibility of copyright rules the CC cannot create, but foster a sense of the mentioned proposal Collective Intelligence ${ }^{3}$ because it facilitates, unmistakably, the collective construction of knowledge. The CC suggests a new way of circulation of cultural production that overflows from traditional forms of copyright protection, reconnecting the author of his work, in that it gives you the power to distribute it to your goal ${ }^{4}$.

In fact, the $\mathrm{CC}$ licenses are in alternatives to transmedia storytelling, appropriate to that ICTs provide in today's information environment for the benefit of the flow of information, access to knowledge and the development of a global culture more smoothly and better opportunities. Indeed, the

\footnotetext{
${ }^{1}$ Lemos (2005a).

${ }^{2}$ Paranaguá \& Branco (2009) 115.

${ }^{3}$ Lèvy (1993).

${ }^{4}$ Soares (2002).
} 
participation of other actors in transmedia storytelling depends on the license / freedom that the author would like to print your immaterial work.

\section{Conclusions}

The following can be listed as conclusions of this research:

1- The social logic of innovation, productivity and economic growth has not been achieved by "legislative time" that governing relations copyright;

2- The potential of transmedia narrative can be, in this sense, better suited for the CC licenses according to the possibilities offered or restriction of movement consented by the author of immaterial work.

\section{References}

Castells, M. (2003). A galáxia Internet: reflexões sobre Internet, negócios e sociedade. Rio de Janeiro: Jorge Zahar Ed.

Castells, M. (2007). A sociedade em rede. 10. ed. São Paulo: Paz e Terra, v.1.

Fonseca, A. A. (2006) Copyleft: A utopia da pane no sistema. Revista de Economía Política de las tecnologias de la información y comunicación, v. VIII, n. 2, mayo - ago. <http://seer.ufs.br/index.php/eptic/article/view/286/284>.

Fundação Getútlio Vargas. (2011). Escola de Direito do Rio de Janeiro, Centro de Tecnologia e Sociedade. Direitos Autorais em reforma. Rio de Janeiro <http://bibliotecadigital.fgv.br/dspace/bitstream/handle/10438/8789/CTS\%20$\% 20$ Direitos\%20Autorais\%20em\%20Reforma.pdf?sequence $=1$

Gosciola, V. (2012). Narrativa transmídia: conceituação e origens. In: Campalans, C; Renó, D.; Gosciola, V. (Org). Narrativas transmedia: entre teorias y prácticas. Bogotá: Universidad del Rosario.

Jenkins, H. (2009). Cultura da Convergência. São Paulo: Aleph.

Lemos, R. (2005a). Creative Commons, mídia e as transformações recentes do direito da propriedade intelectual. Revista Direito GV, v. 1, n. 1, p. 181-187. <http://bi bliotecadigital.fgv.br/dspace/bitstream/handle/10438/2797/Creative_Commons_ Midia_e_Transformacoes_recentes_do_Direito_da_PI.pdf?sequence $=1$

Lemos, R. (2005b). Direito, Tecnologia e Cultura. Rio de Janeiro: Editora FGV. <http://virtualbib.fgv.br/dspace/handle/10438/2190>

Lemos, R., \& S.V. Branco (2006). Copyleft, Software Livre e Creative Commons: A Nova Feição dos Direitos Autorais e as Obras Colaborativas. Revista de Direito Administrativo, v. 243, p. 180-210. <http://virtualbib.fgv.br/dspace/handle/104 38/2796>.

Lessing, L. (2005). Cultura Livre: como a grande mídia usa a tecnologia e a lei para barrar a criação cultural e controlar a criatividade. São Paulo, Trama. <http://w ww.scribd.com/doc/5266831/Lawrence-Lessig-Cultura-Livre>

Lévy, P. (1993). As tecnologias da inteligência: o futuro do pensamento na era da informática. Rio de Janeiro: Ed. 34.

Lima, C. M., Santini, R. M. \& A. M. Lisboa (2007). O trabalho imaterial, produção colaborativa, e economia de dádiva na sociedade da informação. In: Encontro Nacional de Pesquisa em Ciência da Informação, 8. Salvador-BA, 28-31 out. 
Anais do VIII ENANCIB. <http://www.enancib.ppgci.ufba.br/artigos/GT5-096.pdf $>$.

Lima, C. M., \& R. M. Santini (2008a). Produção colaborativa na sociedade da informação. Rio de Janeiro: E-papers. <http://tinyurl.com/lcs6fy5>.

Lima, C. M. \& R. M. Santini. (2008b). Copyleft e licenças criativas de uso de informação na sociedade da informação. Ci. Inf., Brasília, v. 37, n. 1, abr. <http:// www.scielo.br/scielo.php?script=sci_arttext\&pid=S0100-19652008000100011\& lng=pt\&nrm=iso >. http://dx.doi.org/10.1590/S0100-19652008000100011.

Magalhães, T. S. O. (2008). A criação no ciberespaço e as licenças autorais alternativas. 2008. 83 f. Dissertação (Mestrado em Tecnologias da Inteligência e Design Digital) - Pontifícia Universidade Católica de São Paulo. São Paulo. <http://www.sapientia.pucsp.br//tde_busca/arquivo.php?codArquivo=7523>.

Paranaguá, P. \& S. Branco (2009). Direitos autorais. Rio de Janeiro, 2009. http://bibliotecadigital.fgv.br/dspace/bitstream/handle/10438/2756/Direitos\%20A utorais.pdf?sequence $=5>$.

Pimentel; M. \& H, Fuks (Org.). 2012. Sistemas colaborativos [e-book]. Rio de Janeiro: Elsevier.

Pinheiro, P. P. (2013). Direito Digital. 5. ed. São Paulo, Saraiva.

Renó, D. P., Versuti, A. C. \& L. T. L. Renó (2012). Transmediação e Conectivismo: contemporaneidade para a Educação. In: NUNES LINHARES, R.; LUCENA, S.; VERSUTI, A. (Org.). As redes sociais e seu impacto na cultura e na educação do século XXI. Fortaleza: Edições UFC.

Santos, M. S. (2008). Direito autoral na era digital: impactos, controvérsias e possíveis soluções. 2008. 229 f. Dissertação (Mestrado em Direito das Relações Sociais) Pontifícia Universidade Católica de São Paulo (PUC-SP), São Paulo, 2008. $<$ http://www.sapientia.pucsp.br//tde_busca/arquivo.php?codArquivo=6940>.

Scolari, C. A. (2008). Hipermediaciones: Elementos para una Teoría de la Comunicación Digital Interactiva. Barcelona: Gedisa.

Soares, E. C. M. (2002). Regulação do ciberespaço, controle de fluxos internacionais e direitos de autor: os casos de Portugal e do Brasil. Dissertação (Mestrado em Cultura e Comunicação) - Universidade de Lisboa (Faculdade de Letras), Lisboa, 2012. <http://repositorio.ul.pt/bitstream/10451/7438/1/ulfl126977_tm.pdf>.

Tavares, R. S. V. \& L. C. Anjos (2010).. Copyleft: dos Estados Unidos ao correspondente no Brasil. Revista do CAAP, v. 1, Belo Horizonte, p. 185-208, jan-jun 2010. 
